\title{
50 Myr kimberlite magmatism in the Fort à la Corne field, Sask craton, recorded by zircon megacrysts
}

\author{
Q. Shu $^{1 *}$ ， D.G. Pearson ${ }^{1}$, B. A. Kjargaard ${ }^{2}$ and G. Read $^{3}$ \\ ${ }^{1}$ Dept. of Earth and Atmospheric Sciences, University of Alberta, Edmonton, Canada T6G 2E3, \\ ${ }^{2}$ Geological Survey of Canada, 601 Booth Street, Ottawa, Ontario, Canada, K1A 0E8. \\ ${ }^{3}$ Shore Gold Inc., 300 - 224 4th Ave South, Saskatoon, Saskatchewan, Canada, S7K 5 M5. \\ *qshu1@ualberta.ca
}

\section{Introduction}

Zircon megacrysts from kimberlites appear to have a direct relationship to the magmatic activity that lead to the eruption of their host kimberlites because i) they yield kimberlite eruption ages (Davis, 1977) and ii) their trace element patterns and concentrations significantly differ from crustal zircons, most significantly by the absence of a negative Eu anomaly (Belousova et al., 2002). These are also the features of a large suite of zircon megacrysts from heavy mineral concentrates separated during diamond evaluation of the Orion South kimberlites of Fort à la Corne, central Saskatchewan that erupted through the Sask craton.

Here we seek to use this large suite of kimberlite-derived zircons to evaluate i) the potential age range of kimberlite activity within a single kimberlite cluster and ii) examine via tracer Hf isotopes evidence for any temporal evolution of the megacryst source magma.

\section{$\mathrm{U}-\mathrm{Pb}$ and $\mathrm{Hf}$ isotope results}

We analysed 106 zircon megacrysts from 3 distinct kimberlite phases; i) the Pense kimberlite ii) Early Joli Fou (EJF), kimberlite and iii) Late Joli Fou (LJF) kimberlite from the Fort à la Corne field by LA-ICPMS for trace elements and U-Pb and $\mathrm{Hf}$ isotope ratios. The U-Pb ages have a total range of 95-150 Ma, defining a spread of $\sim 55 \mathrm{Myr}$, with a single kimberlitic zircon giving an age of $1.86 \mathrm{Ga}$, coincident with the Transhudson orogeny. The data define a main age cluster from 95 to 108 Ma (75\% of zircons: Fig.1), overlapping with ages obtained from U-Pb dating of groundmass perovskite (Kjarsgaard et al., 2017), which should record the low-pressure crystallization of kimberlite along with its primary geochemical and isotopic signature. Such U-Pb perovskite ages from Fort à la Corne yield a main peak in the age of volcanism between 92.5 and $103.2 \mathrm{Ma}$, in agreement with our main zircon U-Pb age peak, with a precursor event at $115 \mathrm{Ma}$ (Kjarsgaard et al., 2017). This age range for the majority of FALC kimberlite magmatism is in agreement with earlier ages of 96 and 98 Ma determined with the Rb-Sr isotope system on phlogopite by Lehnert-Thiel et al. (1992) and Hegner et al. (1995), respectively. The close temporal relationship between groundmass crystallisation ages and zircon megacryst ages suggests a genetic relationship between the zircons and the host kimberlites for a large proportion ( 73\% using Gaussian mixture modeling - Fig. 1) of zircons. However, prior to this peak in Cretaceous kimberlite magmatism, the zircon age spectrum (Fig.1) clearly indicates that at least 5 periods of older magmatism affected the basal lithospheric mantle of the Sask craton at 110-120Ma (9\%), 124-127Ma (5\%), 132-139 Мa (8\%),143-150 Ма (2\%) and $1860 \mathrm{Ma}(1 \%)$. The older 3 age clusters have not been recorded as crystallization ages in any of the erupted units of the FALC cluster so far, hence the zircon megacryst ages appear to be yielding information about kimberlite-related activity that may have stalled in the lithospheric mantle, without erupted equivalents, that were later sampled by the more voluminous phase of activity in late mid-Creataceous times.

The Hf isotope systematics vary systematically between the different age populations (Fig.2). The youngest zircons (95 to $108 \mathrm{Ma}$ ) show a large range in initial Hf isotope compositions with $\varepsilon \mathrm{Hf}(\mathrm{t})$ values from -0.5 to +7.3 . Older zircons grew from magmas with significantly more radiogenic $\varepsilon H f(t)$, up to +11.7 . The 110-120 Ma zircons have $\varepsilon H f(t)$ from +3.5 to +11 ; the 124-127 Ma zircons possess 
the most radiogenic $\mathrm{Hf}$ isotope composition with $\varepsilon \mathrm{Hf}(\mathrm{t})$ from +7.7 to +11.7 ; the 132-139 Ma zircons have similarly radiogenic $\varepsilon \mathrm{Hf}(\mathrm{t})$ from +9.8 to +11 while the $143-150$ Ma zircons yield very constant $\varepsilon \mathrm{Hf}(\mathrm{t})$ values from +6.6 to +6.9 . The single Proterozoic zircon $(1.86 \mathrm{Ga})$ also originated from a source with a depleted mantle signature $(\varepsilon \mathrm{Hf}(\mathrm{t}):+3.9 \pm 0.7)$.

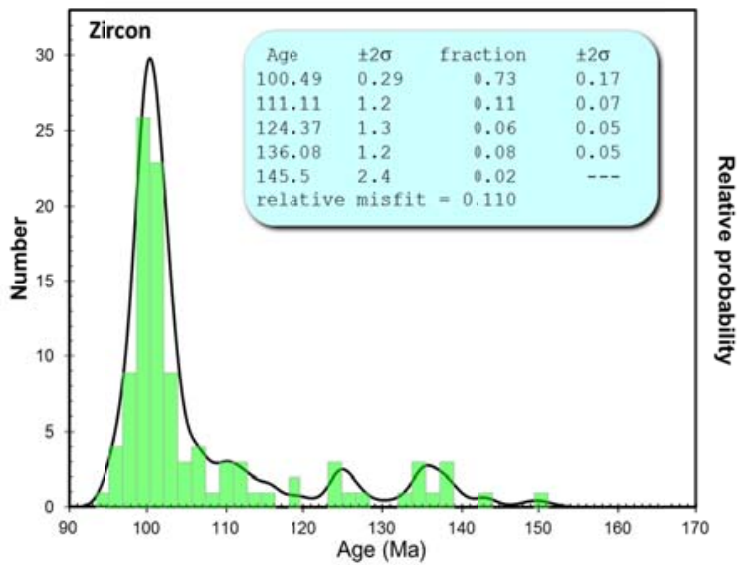

Fig. 1 The probability distribution of U-Pb ages of zircons from the kimberlites erupted in the Fort à la Corne field, central Saskatchewan through the Sask craton. Inset is a Gaussian mixture model of possible age components in the data derived from ISOPLOT.

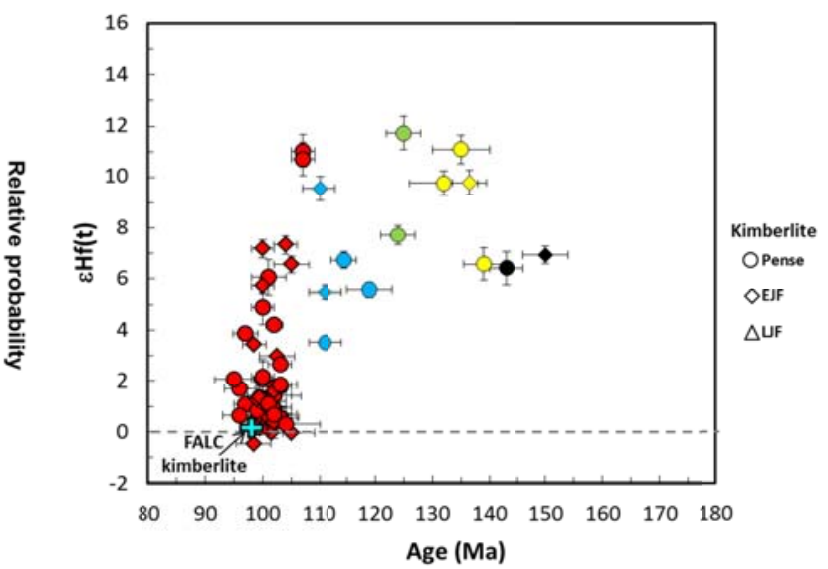

Fig. $2 \mathrm{U}-\mathrm{Pb}$ ages versus $\varepsilon \mathrm{Hf}(\mathrm{t})$ of zircons from the 3 separate kimberlite phases (Pense, EJF, LJF) in the Fort à la Corne field, compared with kimberlite eruption age (U-Pb age from perovskite: Kjarsgaard et al., 2017, where available for U-Pb zircon age). Uncertainties are 95\% confidence. The colour coding is based on distinct age groupings in Fig.3

\section{Discussion}

Our study on kimberlitic zircons shows that long-lived kimberlitic magmatism affected the lithospheric mantle of the Sask craton from 1860 to 95 Ma in at least 5 main age clusters some of which have not been found as erupted kimberlites at the craton surface so far (Fig.3). The ages of about $75 \%$ of the zircons overlap with the time of their host kimberlite magma emplacement as defined by $\mathrm{U}-\mathrm{Pb}$ perovskite and $\mathrm{Rb}-\mathrm{Sr}$ mica dating. This indicates a direct relation of the zircons to the kimberlite magma, i.e. that they were crystallized from a magma closely relatted in time and space to the surface expression of kimberlite magma. Perovskites from kimberlites in the Fort à la Corne field defined the main period of kimberlite magmatism over a timespan from 115 - 93 Ma in the central Sask craton, while our study on kimberlitic zircon megacrysts from the same kimberlite cluster indicates 4 more periods of pre-cursor magmatism besides the main period in the mid-Cretaceous (Fig.3). Around 25\% of the zircon population yield much older ages than the host kimberlite eruption ages as determined by groundmass perovskite and phlogopite and indicate a significant period of kimberlite activity in one cluster, over a $55 \mathrm{Myr}$ period. The extended period of kimberlite activity in the FALC cluster is in line with protracted, yet punctuated periods of kimberlite magmatism seen in other clusters and fields (e.g., Lac de Gras, Sarkar et al., 2015; Chidliak, Heaman et al., 2015) and even within individual eruptive bodies, such as Renard (Ranger et al., 2017). Interestingly, the oldest of the Mesozoic zircon ages at FALC overlap the main phase of kimberlite activity recorded in the Chidliak cluster, Baffin Island and is, to date, the westernmost expression of this Jurassic/Early Cretaceous kimberlite activity that spans N. America.

Most kimberlite bodies in the Fort à la Corne field are composed of more than one pulse of magma that transported zircons with very different Hf isotope compositions. For example, five eruptive events occurred from 103-99 Ma at the Star kimberlite, and seven eruptive events occurred from $103-95 \mathrm{Ma}$ at the Orion South kimberlite (Kjarsgaaard et al., 2017). Our youngest zircons (95 to $108 \mathrm{Ma}$ ) show a continuous vertical trend of $\mathrm{Hf}$ isotope composition with $\varepsilon \mathrm{Hf}(\mathrm{t})$ from -0.5 to +7.3 (Fig.2), with the majority clustering around 0 to +2 . We speculate that the younger parental magmas 
originate from a magma source region similar to OIB, beneath the lithosphere. The generation of the more radiogenic $\mathrm{Hf}$ isotope compositions likely reflects varying interaction with depleted cratonic mantle. The older zircons show more radiogenic Hf isotope composition with $\varepsilon \mathbf{H f}(\mathrm{t})$ from +4 to +12 (Fig.2). Apparently, the contribution of a depleted mantle source plays a vital role in generating the magmas that crystallized the older zircons. The older parental kimberlite magmas, lacking the OIBsource signature, point to the depleted lithospheric source region and may have suffered thermal death in the lithosphere, explaining the lack of erupted kimberlites of these ages in the greater Sask craton.
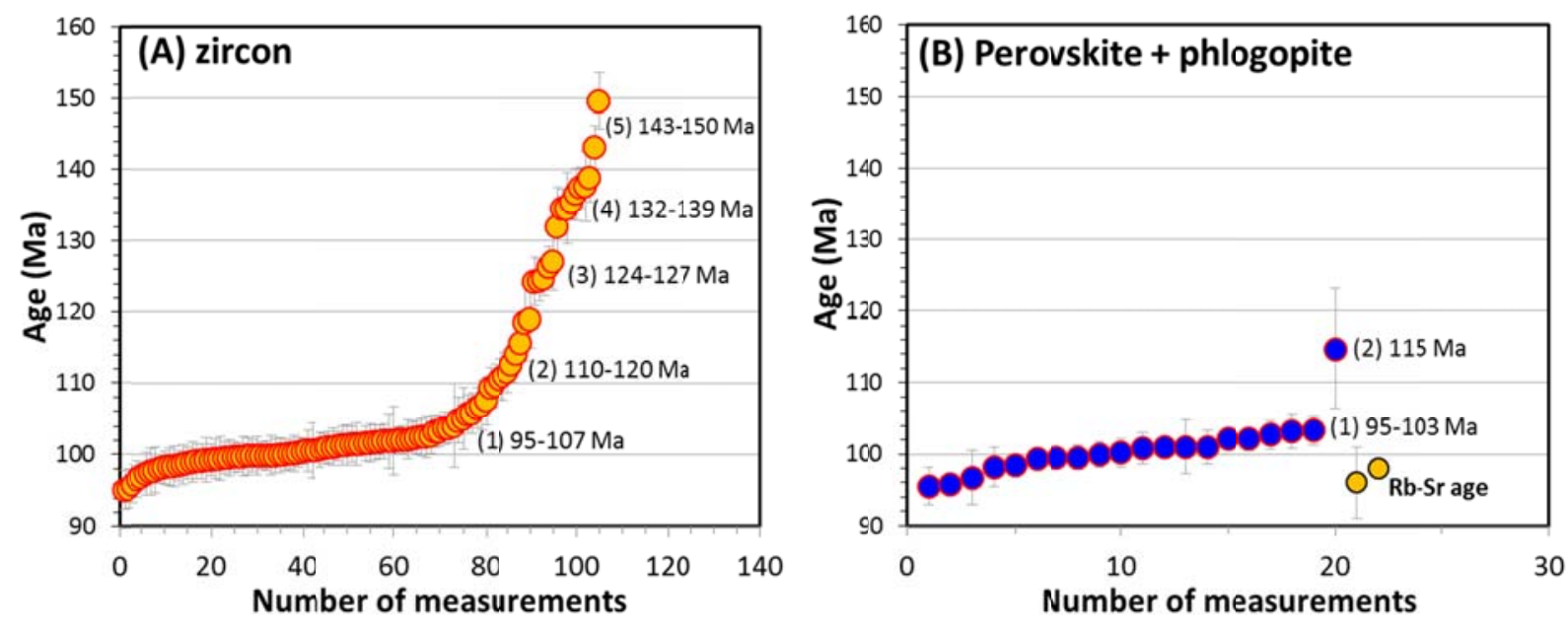

Fig. 3 Comparison of kimberlite and zircon megacryst ages from the Fort à la Corne field: (A) U-Pb mantle zircon age; (B) U-Pb perovskite (blue circles) (Kjarsgaard et al., 2017) and Rb-Sr model age from phlogopite (yellow circles; Lehnert-Thiel et al., 1992 ; Hegner et al., 1995).

\section{References}

Belousova E, Griffin WL, O’Reilly SY, Fisher NI (2002) Igneous zircon: trace element composition as an indicator of source rock type. Contrib. Mineral. Petrol. 143: 602-622.

Davis GL (1977) The ages and uranium contents of zircons from kimberlites and associated rocks. Carnegie Inst. Wash. Yearbook 76: 631-635.

Heaman LM, Pell, JA, Grutter H, Creaser RA (2015) U-Pb geochronology and Sr/Nd isotope compositions of groundmass perovskite from the newly discovered Jurassic Chidliak kimberlite field, Baffin Island, Canada. Earth Planet. Sci. Lett. 415: 183-199.

Hegner E, Roddick JC, Fortier SM, Hulbert L (1995) Nd, Sr, Pb, Ar and O isotopic systematics of Sturgeon Lake kimberlite, Saskatchewan, Canada: constraints on emplacement age, alteration and source composition. Con. Min. Pet., 120: 212-222.

Kjarsgaard BA, Heaman LM, Sarkar C, Pearson DG (2017) The North America mid-Cretaceous kimberlite corridor: Wet, edge driven decompression melting of an OIB-type deep mantle source .Geochemistry, Geophysics, Geosystems (in review).

Lehnert-Thiel K, Loewer R, Orr RG, Robertshaw P (1992) Diamond-bearing kimberlites in Saskatchewan, Canada: The Fort à la Corne case history. Exp. Min. Geol. 1: 391-403.

Ranger IM, Heaman LM, Pearson DG, Laroulandie C, Lepine I, Zhuk V (2017) Punctuated, longlived emplacement history of kimberlites from the Renard cluster, Superior Province, Canada indicated by new high precision U-Pb groundmass perovskite dating. 11th International Kimberlite Conference Extended Abstract No. 11IKC- 4493.

Sarkar C, Heaman LM, Pearson DG (2015) Duration and periodicity of kimberlite volcanic activity in the Lac de Gras kimberlite field, Canada and some recommendations for kimberlite geochronology. Lithos, 218-219: 155-166. 